\title{
Pengaruh Lingkungan Kerja Dan Stress Kerja Terhadap Kinerja Karyawan \\ (Studi Kasus di PT. KEONG NUSANTARA ABADI)
}

\author{
Sugandha \\ Manajemen, Universitas Buddhi Dharma, Banten, Indonesia
}

\begin{abstract}
ABSTRAK
Penelitian ini dilakukan adalah dengan menyebar kuesioner, sedangkan untuk metode penelitian adalah dengan metode deskriptif. Dalam melakukan penelitian ini penulis menggunakan analisis koefisien korelasi, analisis regresi berganda uji $\mathrm{F}$ serta uji t.Dari hasil analisis regresi linier berganda diperoleh persamaan ini menunjukkan persamaan $\mathrm{Y}=5.825+0,840 \mathrm{X}_{1}+0,293 \mathrm{X}_{2}$ di mana nilai konstanta (a) positif 5.825 menunjukkan besarnya Kinerja Karyawan pada PT. Keong Nusantara Abadi, jika tidak ada variabel lingkungan kerja dan stress kerja adalah positif 5.825 satuan, nilai koefisien regresi $\left(b_{1}\right)$ variabel lingkungan kerja positif sebesar 0.840 berarti terdapat pengaruh positif dari variabel lingkungan kerja terhadap kinerja karyawan pada PT. Keong Nusantara Abadi, sebesar 0.840 dengan asumsi variabel lainnya tetap atau konstan dan nilai koefisien regresi $\left(b_{2}\right)$ variabel harga positif sebesar 0.293 berarti terdapat pengaruh positif dari variabel stress kerja terhadap kinerja karyawan pada PT. Keong Nusantara Abadi, sebesar 0.293 dengan asumsi variabel lainnya tetap atau konstan. Nilai adjusted $\mathrm{R}^{2}$ dalam penelitian ini sebesar 74.1\% lingkungan kerja, dan stress kerja memberikan sumbangan sebesar $74.1 \%$ terhadap kinerja karyawan pada PT. Keong Nusantara Abadi sementara 25,9 \% dijelaskan oleh sebab-sebab yang lain. Nilai $t$ hitung lingkungan kerja $11.004>t_{\text {tabel }}$ $1,966$ dan $.0 .000<0.05)$ dan nilai $t$ hitung stress kerja $4.398>t_{\text {tabel }} 1,966$ dan $.0 .000<$ 0.05) sehingga menyatakan bahwa lingkungan kerja dan stress kerja berpengaruh positif secara parsial terhadap kinerja karyawan pada pada PT. Keong Nusantara Abadi

Hasil uji F diperoleh hasil untuk Nilai $F$ hitung sebesar 142.861 dengan nilai signifikansi sebesar 0.000 sehingga nilai $F$ hitung $>F$ tabel atau $252.007>3.09$ atau tingkat signifikasi (sig) $0.000<0.05$, maka dapat disimpulkan berpengaruh secara simultan (bersama-sama) antara lingkungan kerja dan stress kerja terhadap kinerja karyawan pada PT. Keong Nusantara Abadi.
\end{abstract}

Kata Kunci : Lingkungan kerja, stress kerja dan kinerja karyawan 


\section{ABSTRACT}

This research was conducted by distributing questionnaires, while the research method was descriptive method. In conducting this research the author uses correlation coefficient analysis, multiple regression analysis $F$ test and $t$ test. From the results of multiple linear regression analysis this equation shows the equation $Y=5.825+0.840 X 1+0.293 X 2$ where the value of a constant (a) positive 5.825 shows the magnitude Employee Performance at PT. Keong Nusantara Abadi, if there is no work environment variable and work stress is positive 5,825 units, the regression coefficient value (b1) positive work environment variable is 0.840 means that there is a positive influence of the work environment variable on employee performance at PT. Keong Nusantara Abadi, amounting to 0.840 with the assumption that other variables are constant or constant and the regression coefficient (b2) positive price variable is 0.293 means that there is a positive effect of work stress variables on employee performance at PT. Keong Nusantara Abadi, amounting to 0.293 assuming other variables are constant or constant. Adjusted R2 value in this study amounted to $74.1 \%$ work environment, and work stress contributed $74.1 \%$ to the performance of employees at PT. Keong Nusantara Abadi while $25.9 \%$ is explained by other reasons. The t value of the work environment is $11,004>t$ table 1,966 and. $0,000<0.05)$ and the work stress $t$ count is 4,398> $t$ table 1,966 and. $0,000<0.05)$ so that the work environment and work stress partially have a positive effect on employee performance at PT. Keong Nusantara Abadi The results of the $F$ test obtained results for the calculated $F$ value of 142,861 with a significance value of 0,000 so that the calculated $F$ value $>F$ table or 252,007> 3.09 or the significance level (sig) 0,000 $<0.05$, it can be concluded that the environment is simultaneous work and work stress on employee performance at PT. Keong Nusantara Abadi.

Keywords: Work environment, work stress and employee performance

\section{PENDAHULUAN}

Suatu perusahaan dalam melaksanakan kegiatannya, baik perusahaan yang bergerak di bidang industri, perdagangan maupun jasa akan berusaha untuk mencapai tujuan yang telah ditetapkan sebelumnya. Satu hal yang penting yaitu bahwa keberhasilan berbagai aktivitas di dalam perusahaan dalam mencapai tujuan bukan hanya tergantung pada keunggulan teknologi, dana operasi yang tersedia, sarana atau prasarana yang dimiliki, melainkan juga tergantung pada aspek sumber daya manusia. Faktor sumber daya manusia ini merupakan elemen yang harus diperhatikan oleh perusahaan, terutama bila mengingat bahwa era perdagangan bebas akan segera dimulai, di mana iklim kompetisi yang dihadapi akan sangat berbeda. Hal ini memaksa setiap perusahaan harus dapat bekerja dengan lebih efisien, efektif, dan produktif. Tingkat kompetisi yang tinggi akan memacu tiap perusahaan untuk mempertahankan kelangsungan hidupnya dengan memberikan perhatian pada aspek sumber daya manusia. Jadi, manusia dapat dipandang sebagai faktor penentu karena ditangan manusialah segala inovasi akan direalisir dalam upaya mewujudkan tujuan perusahaan.

Lingkungan kerja menjadi salah satu faktor yang mempengaruhi kinerja karyawan. Perusahaan juga banyak mengalami masalah seperti : rancangan kerja, kondisi lingkungan, pekerjaan yang berlebihan, sistem pengawasan, dan ketidakjelasan 
tugas, sehingga diperlukan penanganan khusus dan tidak menjadikan beban kerja bagi karyawan dalam melaksanakan tugas serta tanggung jawabnya. Masalah stres kerja di dalam organisasi perusahaan menjadi gejala yang penting diamati sejak mulai timbulnya tuntutan untuk efisiensi di dalam pekerjaan. Masalah stres kerja karyawan berupa peranan pengaruh pimpinan di dalam bekerja, peluang karier yang kurang terbuka dan menunjang, kurangnya dukungan dalam team dikarenakan setiap karyawan hanya mengandalkan dan menonjolkan dirinya demi sebuah jabatan, serta pengaruh dari kondisi lingkungan kerja yang kurang bersih dan terawat. Hal - hal inilah yang menyebabkan tingkat stres kerja meningkat dan perlu dikelola oleh seorang pimpinan perusahaan agar potensi - potensi yang merugikan perusahaan tersebut dapat diatasi.

Sebagai seorang pekerja, lingkungan kerja yang kurang baik dan stres kerja tidak harusnya dialami oleh karyawan, sebagai pekerja yang baik mereka bekerja untuk memenuhi kebutuhan sehari - hari dan merasa nyaman dan aman dalam bekerja, semua tergantung manajemen sumber daya manusia di dalam perusahaan tersebut. Suatu perusahaan bisa mencapai tujuannya jika alat produksinya yaitu manusia dan karyawan bisa mendapatkan hak dan struktur pekerjaan yang jelas. Masalah lingkungan kerja dan stres kerja ini menjadi salah satu faktor untuk menghambat kinerja yang baik di dalam perusahaan tersebut.

Terdapat dua faktor penyebab atau sumber munculnya stres atau stres kerja, yaitu faktor lingkungan kerja dan faktor personal. Faktor lingkungan kerja dapat berupa kondisi fisik, manajemen kantor maupun hubungan sosial di lingkungan pekerjaan. Sedangkan faktor personal bisa berupa tipe kepribadian, peristiwa / pengalaman pribadi maupun kondisi sosial-ekonomi keluarga di mana pribadi berada dan mengembangkan diri.

Stres kerja yang penulis amati selama penulis survei di PT. Keong Nusantara Abadi adalah, karyawan selama mereka bekerja, mereka juga terkadang mengalami stres atau tekanan dalam bentuk yang bermacam - macam. Ada yang mengalami stres atau tekanan dari segi beban kerja atau tuntutan kerja yang berlebih, ada pula yang mengalami stres atau tekanan dalam bentuk kondisi lingkungan kerja yang kurang bersih dan nyaman.

Aspek-aspek penyebab kinerja karyawan seperti kedisiplinan karyawan, kepatuhan karyawan dalam melaksanakan instruksi dari pimpinan, bekerja dengan team, dan pimpinannya dengan baik serta kemampuannya dalam melaksanakan kinerjanya. Dengan ini karyawan akan meningkatkan kinerjanya dan melakukan pekerjaan secara lebih giat sehingga pekerjaan dapat diharapkan lebih cepat dan lebih baik. Begitu juga sebaliknya jika lingkungan kerja dan stres kerja meningkat maka kinerja akan turun juga. Jadi, dengan kata lain lingkungan kerja dan stres kerja akan berpengaruh terhadap kinerja karyawan.

Perumuasan masalah dalam penelitian ini adalah (1) Apakah lingkungan kerja berpengaruh terhadap kinerja karyawan pada PT. Keong Nusantara Abadi? (2) Apakah stres kerja berpengaruh terhadap kinerja karyawan pada PT. Keong Nusantara Abadi? (3) Apakah lingkungan kerja dan stres kerja berpengaruh terhadap kinerja karyawan pada PT. Keong Nusantara Abadi? 
Tujuan penelitian ini adalah (1) Untuk mengetahui pengaruh dari lingkungan kerja terhadap kinerja karyawan pada PT. Keong Nusantara Abadi. (2) Untuk mengetahui pengaruh dari stres kerja terhadap kinerja karyawan pada PT. Keong Nusantara Abadi. (3) Untuk mengetahui pengaruh dari lingkungan kerja dan stres kerja terhadap kinerja karyawan pada PT. Keong Nusantara Abadi.

\section{HASIL DAN PEMBAHASAN}

Pada penelitian ini penulis mengambil beberapa orang atau responden untuk dijadikan sampel dalam menjawab pernyataan-pernyataan yang diajukan penulis mengenai analisis pengaruh lingkungan kerja dan stress kerja terhadap kinerja karyawan pada PT. Keong Nusantara Abadi dalam bentuk beberapa pernyataan atau kuisioner yang diajukan kepada 100 orang atau responden.

\section{Uji Validitas}

Pengujian validitas tiap butir pertanyaan dalam penelitian ini dilakukan dengan mengkorelasikan skor tiap butir dengan skor total. Untuk menguji apakah masingmasing indicator valid atau tidak, dengan membandingkan $r$ hitung dengan hasil perhitungan $\mathrm{r}$ tabel Karena $\mathrm{r}$ hitung $>\mathrm{r}$ tabel dan bernilai positif maka indikator dinyatakan valid.

Tabel 2

Hasil Uji Validitas Kuesioner

\begin{tabular}{|c|c|c|c|c|}
\hline Variabel & $\mathrm{r}$ hitung & $\mathrm{r}$ tabel & Perbandingan & Keterangan \\
\hline \multicolumn{5}{|c|}{ Lingkungan Kerja (X1) } \\
\hline$X_{1-1}$ & .694 & 0,1966 & $\mathrm{r}_{\text {hitung }}>\mathrm{r}_{\text {tabel }}$ & Valid \\
\hline$X_{1-2}$ & .561 & 0,1966 & $r_{\text {hitung }}>r_{\text {tabel }}$ & Valid \\
\hline$X_{1}-3$ & .639 & 0,1966 & $r_{\text {hitung }}>r_{\text {tabel }}$ & Valid \\
\hline$X_{1-4}$ & .609 & 0,1966 & $r_{\text {hitung }}>r_{\text {tabel }}$ & Valid \\
\hline$X_{1}-5$ & .752 & 0,1966 & $r_{\text {hitung }}>r_{\text {tabel }}$ & Valid \\
\hline$X_{1}-6$ & .632 & 0,1966 & $\mathrm{r}_{\text {hitung }}>\mathrm{r}_{\text {tabel }}$ & Valid \\
\hline$X_{1}-7$ & .699 & 0,1966 & $r_{\text {hitung }}>r_{\text {tabel }}$ & Valid \\
\hline$X_{1-8}$ & .521 & 0,1966 & $r_{\text {hitung }}>r_{\text {tabel }}$ & Valid \\
\hline$X_{1-9}$ & .514 & 0,1966 & $r_{\text {hitung }}>r_{\text {tabel }}$ & Valid \\
\hline $\mathrm{X}_{1-10}$ & .359 & 0,1966 & $r_{\text {hitung }}>r_{\text {tabel }}$ & Valid \\
\hline \multicolumn{5}{|c|}{ Stress Kerja $\left(\mathbf{X}_{2}\right)$} \\
\hline $\mathrm{X}_{2-1}$ & .725 & 0,1966 & $\mathrm{r}_{\text {hitung }}>\mathrm{r}_{\text {tabel }}$ & Valid \\
\hline$X_{2}-2$ & .902 & 0,1966 & $r_{\text {hitung }}>r_{\text {tabel }}$ & Valid \\
\hline$X_{2}-3$ & .821 & 0,1966 & $\mathrm{r}_{\text {hitung }}>\mathrm{r}_{\text {tabel }}$ & Valid \\
\hline$X_{2}-4$ & .765 & 0,1966 & $r_{\text {hitung }}>r_{\text {tabel }}$ & Valid \\
\hline$X_{2}-5$ & .759 & 0,1966 & $r_{\text {hitung }}>r_{\text {tabel }}$ & Valid \\
\hline$X_{2}-6$ & .603 & 0,1966 & $r_{\text {hitung }}>r_{\text {tabel }}$ & Valid \\
\hline$X_{2}-7$ & .672 & 0,1966 & $r_{\text {hitung }}>r_{\text {tabel }}$ & Valid \\
\hline $\mathrm{X}_{2}-8$ & .566 & 0,1966 & $r_{\text {hitung }}>r_{\text {tabel }}$ & Valid \\
\hline$X_{2}-9$ & .578 & 0,1966 & $r_{\text {hitung }}>r_{\text {tabel }}$ & Valid \\
\hline $\mathrm{X}_{2}-10$ & .596 & 0,1966 & $\mathrm{r}_{\text {hitung }}>\mathrm{r}_{\text {tabel }}$ & Valid \\
\hline \multicolumn{5}{|c|}{ Kinerja Karyawan $(\mathrm{Y})$} \\
\hline $\mathrm{Y}-1$ & .823 & 0,1966 & $r_{\text {hitung }}>r_{\text {tabel }}$ & Valid \\
\hline
\end{tabular}




\begin{tabular}{|c|c|c|c|c|}
\hline $\mathrm{Y}-2$ & .830 & 0,1966 & $\mathrm{r}_{\text {hitung }}>\mathrm{r}_{\text {tabel }}$ & Valid \\
\hline $\mathrm{Y}-3$ & .438 & 0,1966 & $\mathrm{r}_{\text {hitung }}>\mathrm{r}_{\text {tabel }}$ & Valid \\
\hline $\mathrm{Y}-4$ & .652 & 0,1966 & $\mathrm{r}_{\text {hitung }}>\mathrm{r}_{\text {tabel }}$ & Valid \\
\hline $\mathrm{Y}-5$ & .672 & 0,1966 & $\mathrm{r}_{\text {hitung }}>\mathrm{r}_{\text {tabel }}$ & Valid \\
\hline $\mathrm{Y}-6$ & .207 & 0,1966 & $\mathrm{r}_{\text {hitung }}>\mathrm{r}_{\text {tabel }}$ & Valid \\
\hline $\mathrm{Y}-7$ & .541 & 0,1966 & $\mathrm{r}_{\text {hitung }}>\mathrm{r}_{\text {tabel }}$ & Valid \\
\hline $\mathrm{Y} \mathrm{-8}$ & .282 & 0,1966 & $\mathrm{r}_{\text {hitung }}>\mathrm{r}_{\text {tabel }}$ & Valid \\
\hline $\mathrm{Y} \mathrm{-9}$ & .412 & 0,1966 & $\mathrm{r}_{\text {hitung }}>\mathrm{r}_{\text {tabel }}$ & Valid \\
\hline $\mathrm{Y}-10$ & .585 & 0,1966 & $\mathrm{r}_{\text {hitung }}>\mathrm{r}_{\text {tabel }}$ & Valid \\
\hline
\end{tabular}

Dari tabel 2 diatas, di mana semua nilai $\mathrm{r}$ hitung dari item-item pertanyaan dalam kuesioner lebih besar dari nilai $r$ tabel artinya semua item pertanyaan baik lingkungan kerja $\left(\mathrm{X}_{1}\right)$ dan stress kerja $\left(\mathrm{X}_{2}\right)$ dan kinerja karyawan $(\mathrm{Y})$ valid

\section{Uji Reabilitas}

Uji Reabilitas dilakukan untuk menilai konsisten dari instrument penelitian. Suatu instrument variabel penelitian dikatakan realibel jika Nilai Cronbach's Alpha lebih besar dari standar pengujian (a) 0,70

Tabel 3

Hasil Uji reliabilitas kuesioner

\begin{tabular}{|l|l|c|c|}
\hline \multicolumn{1}{|c|}{ Variabel } & \multicolumn{1}{|c|}{$\begin{array}{c}\text { Nilai Cronbach's } \\
\text { Alpha }\end{array}$} & $\begin{array}{l}\text { Standar } \\
\text { Pengujian }(\mathrm{a})\end{array}$ & Keterangan \\
\hline $\begin{array}{l}\text { Lingkungan Kerja } \\
(\mathrm{X} 1)\end{array}$ & 0.876 & 0,70 & Reliabel \\
\hline Stress Kerja $\left(\mathrm{X}_{2}\right)$ & 0.918 & 0,70 & Reliabel \\
\hline Kinerja Karyawan (Y) & 0.847 & 0,70 & Reliabel \\
\hline
\end{tabular}

Dari tabel 3 terlihat bahwa semua variabel dalam penelitian ini sudah reliable, hal ini terlihat dari nilai cronbach's alpha untuk variabel lingkungan kerja $\left(X_{1}\right)$ stress kerja $\left(\mathrm{X}_{2}\right)$ dan kinerja karyawan $(\mathrm{Y})$ lebih besar $(>)$ 0,70

Hasil Uji Asumsi Regresi

Uji Normalitas

Penelitian ini menggunakan plot probabilitas normal (Normal probability plot) untuk menguji kenormalitasan jika penyebaran data (titik) disekitar sumbu diagonal dan mengikuti arah garis diagonal, maka model regresi memenuhi asumsi Normalitas. 
Normal P-P Plot of Regression Standardized Residual

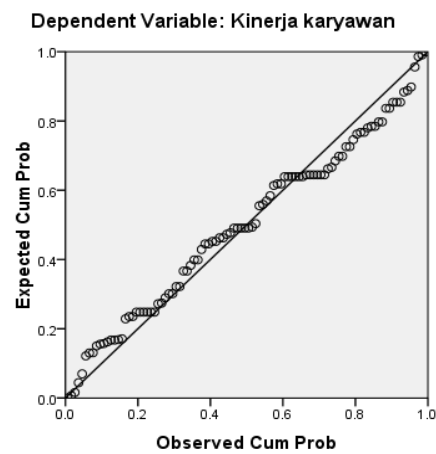

Gambar 2. Hasil Uji Normalitas Menggunakan Grafik P.Plot

Gambar 2 menunjukkan data menyebar di sekitar garis diagonal dan mengikuti arah garis diagonal atau grafik histogram sehingga dapat disimpulkan data tersebut menunjukkan pola distribusi normal. Oleh Karen itu memenuhi asumsi normalitas.

\section{Uji Multikolinearitas}

Uji multikoniearitas penelitian ini menggunakan nilai tolerance dan Variance Inflasion Factor (VIF), dimana nilai tolerance yang rendah sama dengan nilai VIF tinggi. Penelitian ini menggunakan cutoff nilai tolerance $>0.10$ atau sama dengan nilai VIF $>$ 10. (Ghozali, 2010:91). Hasil pengujian multikorelasi model regresi penelitian ini adalah sebagai berikut:

Tabel 4. Hasil Uji Multikolinieritas

\section{Coefficients}

\begin{tabular}{|ll|r|r|}
\hline \multirow{2}{*}{ Model } & \multicolumn{2}{|c|}{$\begin{array}{c}\text { Collinearity } \\
\text { Statistics }\end{array}$} \\
\cline { 2 - 4 } & Tolerance & \multicolumn{1}{c|}{ VIF } \\
\hline $1 \quad$ (Constant) & & \\
& Lingkungan kerja & .682 & 1.465 \\
& Stress kerja & .682 & 1.465 \\
\hline
\end{tabular}

a. Dependent Variable: Kinerja karyawan

Berdasarkan pada tabel 4 diatas hasil perhitungan nilai VIF (Variance Inflation Factor) masing-masing variabel independent dalam model ini dibawah 10 dan nilai torerance-nya berada diatas 10\%(0.10), maka dapat dikatakan model ini bebas dari masalah multikolineritas.

\section{Uji Autokorelasi}

Berdasarkan hasil output SPSS persamaan regresi dalam penelitian ini dimana D-W (Durbin-Watson), sebesar 1,979 untuk nilai $\mathrm{dL}$ adalah 1.6337 dan nilai dU adalah 1.7152, maka nilai 4-dU = 2,2625 dan 4-dL = 2.3937, hal dapat disimpulkan berarti model regresi diatas tidak terdapat masalah autokorelasi. 


\section{Uji Heterokesdatisitas}

Dilakukan untuk menguji apakah dalam sebuah model regresi, terjadi ketidaksamaan varians dari residual dari satu pengamatan ke pengamatan yang lain. Deteksi adanya tidaknya heteroskedastisitas dilakukan dengan melihat ada tidaknya pola tertentu pada grafik scatterplot antara SRESID dan ZPRED

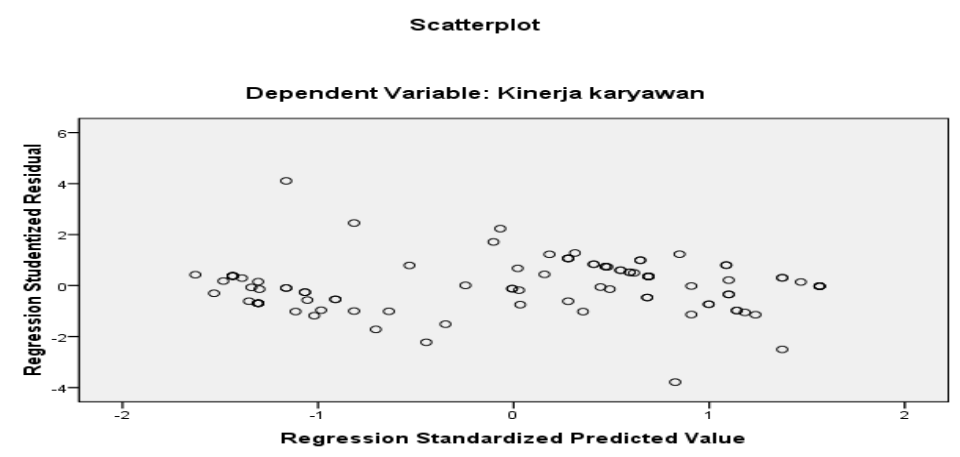

Gambar 4. Grafik Scatterplot

Gambar 4 menunjukkan bahwa titik-titik yang dihasilkan menyebar secara acak dan tidak membentuk pola atau tred garis tertentu.Hal ini berarti bahwa data tersebar di atas dan di bawah angka 0 sehingga model ini bebas dari amsalah heteroskedastisitas.

\section{Analisis Linier Berganda}

Untuk mengetahui ada tidaknya pengaruh antara variabel $X_{1}$ (lingkungan kerja), dan variabel $X_{2}$ (stress kerja), terhadap Y (kinerja karyawan ), serta mengukur kuat tidaknya pengaruh tersebut, maka digunakan analisa regresi berganda dengan perhitungan SPSS (Statistical Package Service Softition), Versi 20.0

\section{Tabel 5. Hasil Perhitungan Regresi Berganda}

\section{Coefficients $^{\mathrm{a}}$}

\begin{tabular}{|c|c|c|c|c|c|c|c|}
\hline \multirow[b]{2}{*}{ Model } & \multicolumn{2}{|c|}{$\begin{array}{c}\text { Unstandardized } \\
\text { Coefficients }\end{array}$} & \multirow{2}{*}{$\begin{array}{c}\text { Standardized } \\
\text { Coefficients } \\
\text { Beta } \\
\end{array}$} & \multirow[b]{2}{*}{$\mathrm{t}$} & \multirow[b]{2}{*}{ Sig. } & \multicolumn{2}{|c|}{$\begin{array}{l}\text { Collinearity } \\
\text { Statistics }\end{array}$} \\
\hline & B & $\begin{array}{l}\text { Std. } \\
\text { Error }\end{array}$ & & & & $\begin{array}{c}\text { Toleranc } \\
\text { e }\end{array}$ & VIF \\
\hline 1 (Constant) & 5.825 & 1.996 & & 2.918 & .004 & & \\
\hline Lingkungan kerja & .840 & .076 & 681 & 11.004 & .000 & .682 & 1.465 \\
\hline Stress kerja & .293 & .067 & .272 & 4.398 & .000 & .682 & 1.465 \\
\hline
\end{tabular}

a. Dependent Variable: Kinerja

karyawan

Berdasarkan tabel diatas dapat dibentuk persamaan regresi berganda :

$$
\mathrm{Y}=5.825+0,840 \mathrm{X}_{1}+0,293 \mathrm{X}_{2}
$$

Persamaan tersebut mempunyai arti sebagai berikut: 
1. Nilai konstanta (a) positif 5.825 menunjukkan besarnya Kinerja Karyawan pada PT. Keong Nusantara Abadi, jika tidak ada variabel lingkungan kerja dan stress kerja adalah positif 5.825 satuan.

2. Nilai koefisien regresi $\left(b_{1}\right)$ variabel lingkungan kerja positif sebesar 0.840 berarti terdapat pengaruh positif dari variabel lingkungan kerja terhadap kinerja karyawan pada PT. Keong Nusantara Abadi, sebesar 0.840 dengan asumsi variabel lainnya tetap atau konstan.

3. Nilai koefisien regresi $\left(b_{2}\right)$ variabel harga positif sebesar 0.293 berarti terdapat pengaruh positif dari variabel stress kerja terhadap kinerja karyawan pada PT. Keong Nusantara Abadi, sebesar 0.293 dengan asumsi variabel lainnya tetap atau konstan.

\section{Uji Koefisien Determinasi $\left(\mathbf{R}^{2}\right)$}

Hubungan antara kualitas pelayanan $\left(X_{1}\right)$, harga $\left(X_{2}\right)$, dan lokasi $\left(X_{3}\right)$ terhadap kepuasan pelanggan $(\mathrm{Y})$ dapat diketahui dari nilai korelasi secara simultan atau $\mathrm{R}$ (Adjusted R square)

\section{Model Summaryb}

\begin{tabular}{|c|c|c|c|c|c|c|c|c|c|}
\hline \multirow[b]{2}{*}{$\begin{array}{l}\text { Mod } \\
\text { el }\end{array}$} & \multirow[b]{2}{*}{$\mathrm{R}$} & \multirow[b]{2}{*}{$\begin{array}{c}\mathrm{R} \\
\text { Square }\end{array}$} & \multirow[b]{2}{*}{$\begin{array}{c}\text { Adjuste } \\
\text { d R } \\
\text { Square }\end{array}$} & \multirow[b]{2}{*}{$\begin{array}{l}\text { Std. Error } \\
\text { of the } \\
\text { Estimate }\end{array}$} & \multicolumn{5}{|c|}{ Change Statistics } \\
\hline & & & & & $\begin{array}{c}\text { R } \\
\text { Square } \\
\text { Change }\end{array}$ & $\begin{array}{c}\mathrm{F} \\
\text { Change }\end{array}$ & df1 & df2 & $\begin{array}{c}\text { Sig. F } \\
\text { Change }\end{array}$ \\
\hline 1 & $.864^{\mathrm{a}}$ & .747 & .741 & 3.614 & .747 & 142.861 & 2 & 97 & .000 \\
\hline
\end{tabular}

a. Predictors: (Constant), Stress kerja,

Lingkungan kerja

b. Dependent Variable:

Kinerja karyawan

Sumber : SPSS 20.00

Berdasarkan hasil perhitungan dengan SPSS for window nilai adjusted $R^{2}$ dalam penelitian ini sebesar $74.1 \%$ lingkungan kerja, dan stress kerja memberikan sumbangan sebesar $74.1 \%$ terhadap kinerja karyawan pada PT. Keong Nusantara Abadi sementara 25,9\% dijelaskan oleh sebab-sebab yang lain.

\section{Uji t}

Melalui penghitungan data dengan menggunakan program SPSS Release 20, dapat diketahui nilai thitung seperti dalam tabel sebagai berikut: 
Tabel T

Coefficients ${ }^{\mathrm{a}}$

\begin{tabular}{|c|c|c|c|c|c|c|}
\hline \multirow{2}{*}{\multicolumn{2}{|c|}{ Model }} & \multicolumn{2}{|c|}{$\begin{array}{l}\text { Unstandardize } \\
\text { d Coefficients }\end{array}$} & \multirow{2}{*}{$\begin{array}{c}\begin{array}{c}\text { Standardized } \\
\text { Coefficients }\end{array} \\
\text { Beta }\end{array}$} & \multirow[b]{2}{*}{$\mathrm{t}$} & \multirow[b]{2}{*}{ Sig. } \\
\hline & & B & $\begin{array}{l}\text { Std. } \\
\text { Error }\end{array}$ & & & \\
\hline & (Constant) & 5.825 & 1.996 & & 2.918 & .004 \\
\hline & Lingkungan kerja & .840 & .076 & 681 & 11.004 & .000 \\
\hline & Stress kerja & .293 & .067 & 272 & 4.398 & .000 \\
\hline
\end{tabular}

a. Dependent Variable: Kinerja karyawan

a. Variabel lingkungan kerja secara parsial berpengaruh positif dan signifikan (nilai $\mathrm{t}$ hitung lingkungan kerja $11.004>$ tabel 1,966 dan $.0 .000<0.05)$ terhadap kinerja karyawan pada PT. Keong Nusantara Abadi (Y).

b. Variabel stress kerja secara parsial berpengaruh positif dan signifikan (nilai $t_{\text {hitung }}$ stress kerja $4.398>$ tabel 1,966 dan $.0 .000<0.05$ ) terhadap kinerja karyawan pada PT. Keong Nusantara Abadi (Y).

\section{Uji Secara Serentak ( UJi F)}

Melalui penghitungan data dengan menggunakan program SPSS Release 20, dapat diketahui nilai Fhitung seperti dalam tabel sebagai berikut:

Tabel F

ANOVA $^{b}$

\begin{tabular}{|c|c|c|c|c|c|c|}
\hline \multicolumn{2}{|c|}{ Model } & $\begin{array}{l}\text { Sum of } \\
\text { Squares }\end{array}$ & $\mathrm{df}$ & $\begin{array}{l}\text { Mean } \\
\text { Square }\end{array}$ & $\mathrm{F}$ & Sig. \\
\hline \multirow[t]{3}{*}{1} & Regression & 3731.985 & 2 & 1865.992 & 142.861 & $.000^{a}$ \\
\hline & Residual & 1266.975 & 97 & 13.062 & & \\
\hline & Total & 4998.960 & 99 & & & \\
\hline
\end{tabular}

a. Predictors: (Constant), Stress kerja, Lingkungan

kerja

b. Dependent Variable: Kinerja

karyawan

Dari hasil uji $\mathrm{F}$ diperoleh hasil untuk Nilai $\mathrm{F}$ hitung sebesar 142.861 dengan nilai signifikansi sebesar 0.000 sehingga nilai $\mathrm{F}$ hitung $>\mathrm{F}$ tabel atau $252.007>3.09$ atau tingkat signifikasi (sig) $0.000<0.05$, maka dapat disimpulkan berpengaruh secara simultan (bersama-sama) antara lingkungan kerja dan stress kerja terhadap kinerja karyawan pada PT. Keong Nusantara Abadi. 


\section{Daftar Pustaka}

Alwi, Syafaruddin. Perilaku Organisasi. Jakarta Selatan: Salemba Empat. 2015.

Bagia, I Wayan. Perilaku Organisasi. Yogyakarta: Graha Ilmu. 2014.

Dessler, Gary. Manajemen Sumber Daya Manusia. Jakarta Selatan: Salemba Empat.2015.

Feriyanto. Andri, S.E. dan Shyta Triana. Endang, S.E. Pengantar Manajemen (3 in 1). Yogyakarta: Media Tera. 2015.

Hamid, Sanusi. Manajemen Sumber Daya Manusia Lanjutan. Yogyakarta: Alfabeta. 2014.

Junaidi. Tabel Titik Persentase Distribusi F Untuk Probabilita =0,05. http:/ /junaidi chaniago.wordpress.com. 2010.

Yani, H. M. Manajemen Sumber Daya Manusia. Bogor: Mitra Wacana Media. 2014.

Kasmir. Manajemen Sumber Daya Manusia. Depok: Raja Grafindo Persada. 2015.

Makmuri. Perilaku Organisasi. Yogyakarta: Gadjah Mada University Press. 2014.

Ma'ruf Abdullah, Irham. M. Manajemen Dan Evaluasi Kinerja Karyawan. Yogyakarta: Aswaja Pressindo. 2014.

Mulyadi, Deddy. Perilaku Organisasi Dan Kepemimpinan Pelayanan. Jakarta: Rajawali Pers. 2015.

Noe, Raymond A., Hollendbeck John R., dkk. Manajemen Sumber Daya Manusia. Jakarta: Mitra Wacana Media. 2014.

Nuraini, T. Manajemen Sumber Daya Manusia. Pekan Baru: Yayasan Aini Syam. 2013.

Rasto. Manajemen Perkantoran Paradigma Baru. Bandung: Alfabeta. 2015.

Sagala, Ella Jauvani. Manajemen Sumber Daya Manusia. Depok: Raja Grafindo Persada. 2013.

Suparyadi. Manajemen Sumber Daya Manusia. Jakarta: Andi Publisher. 2016.

Supriyatin. Manajemen Sumber Daya Manusia. Jilid ke-1. Jakarta: Mitra Kreatif. 2013.

Sufren dan Yonathan Nathanael. Mahir Menggunakan SPSS Secara Otodidak. Jakarta: Elex Media Komputindo. 2013.

Sutrisno, Edy. Manajemen Sumber Daya Manusia. Edisi Pertama. Cetakan Pertama. Jakarta: Kencana. 2013.

Sugiyono. Metode Penelitian Kuantitatif, Kualitatif Dan R\&D. Cetakan ke-19. Bandung: Alfabeta. 2013.

Sugiyono. Metode Penelitian Kuantitatif, Kualitatif Dan R\&D. Cetakan ke-20. Bandung: Alfabeta. 2014.

Sugiyono. Metode Penelitian Kuantitatif, Kualitatif Dan R\&D. Cetakan Ke-22. Bandung: Alfabeta. 2015.

Sudaryono, Caguk Margono. Pengembangan Instrumen Penelitian. Edisi Ke-1. Yogyakarta: Graha Ilmu. 2013.

Sedarmayanti. Manajemen Sumber Daya Manusia. Bandung: Refika Aditama. 2013.

Wukir. Manajemen Sumber Daya Manusia Dalam Organisasi. Yogyakarta: MultiPresindo. 2013. 